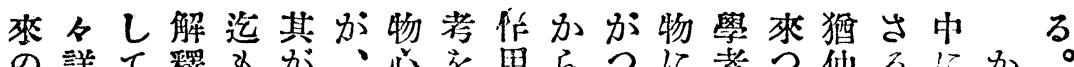

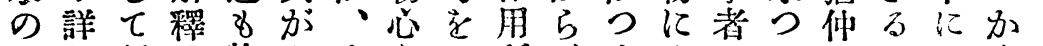

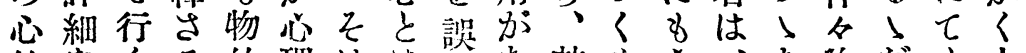

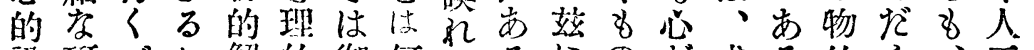
㒛研べ〉解的御何万るにの㤎或る的ら、工

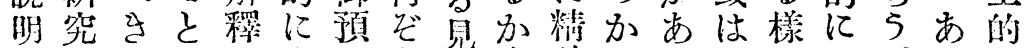

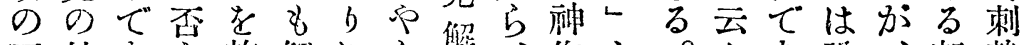

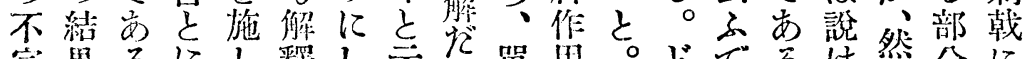

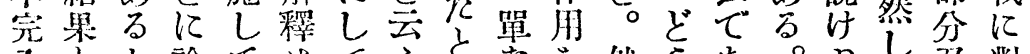

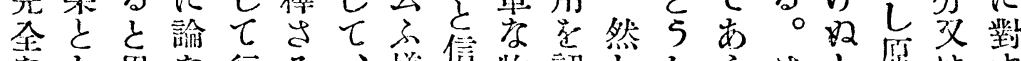

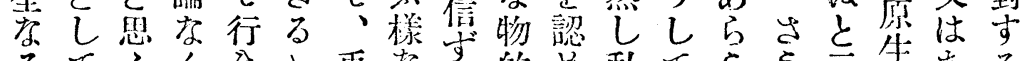

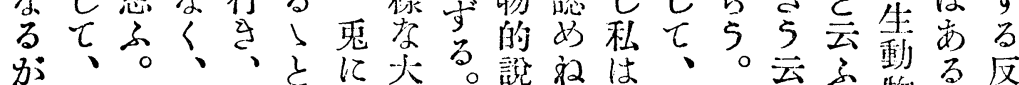

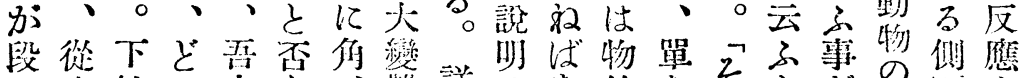

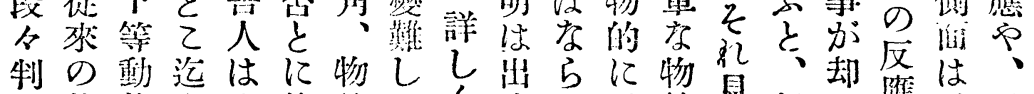

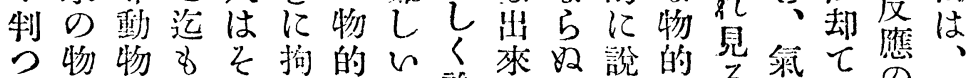

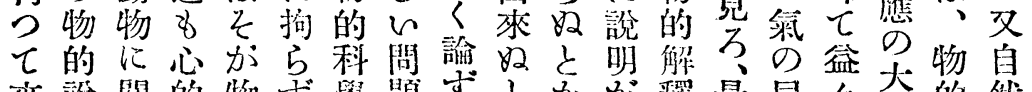

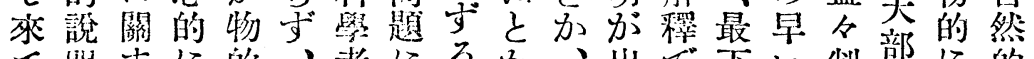
$\tau$ 间与に的・者にる各、出で下心制部反的

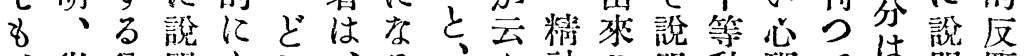

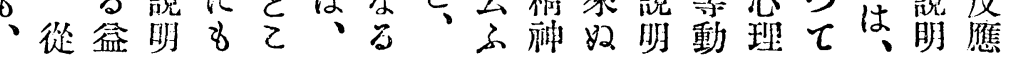

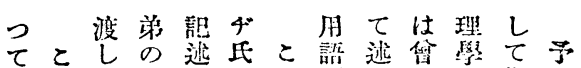

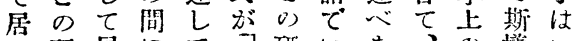

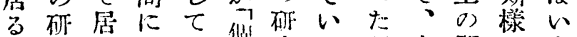

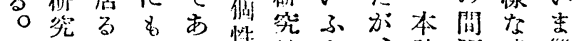

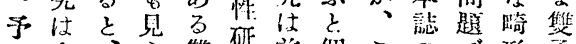

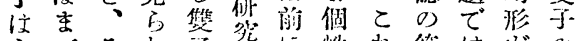

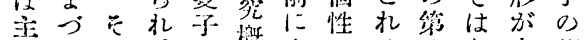

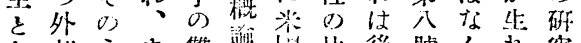

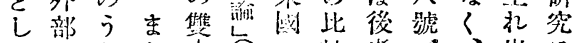

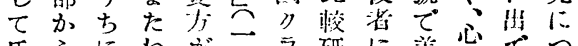

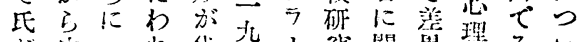

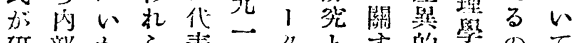

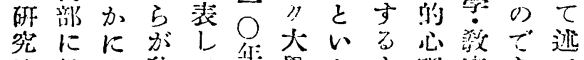
法進 \& 教て 留學

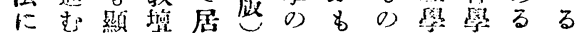

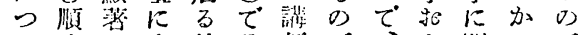

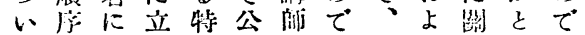
てである临にであ特心゙方ま

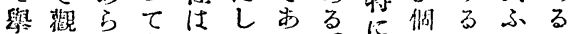

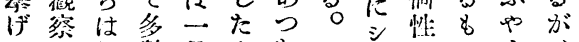

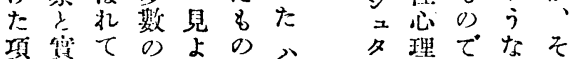

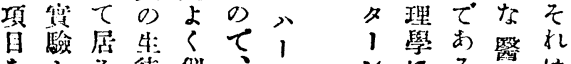

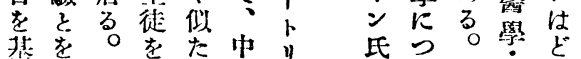

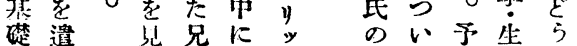

說にそ 明過は がざ單

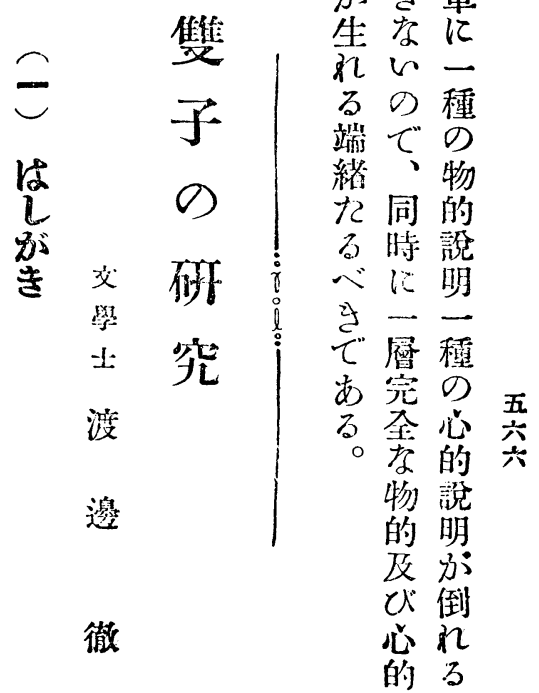


化一あかてあたのれ單合特つナふつ

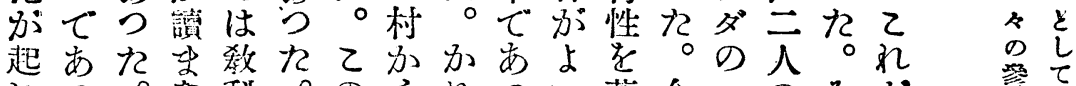

㘜

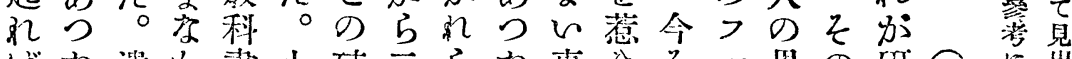

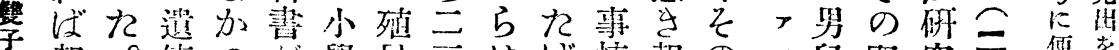

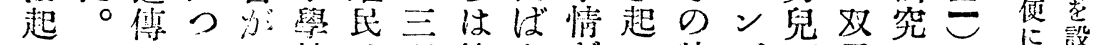

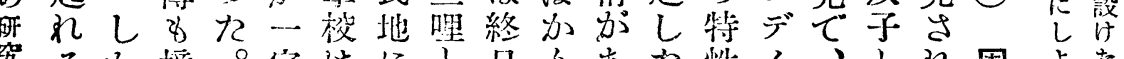

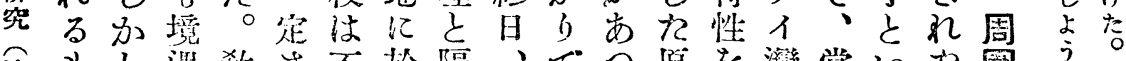

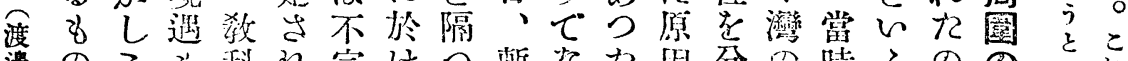

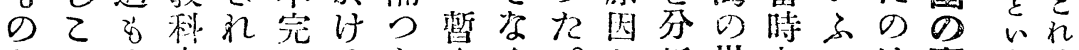

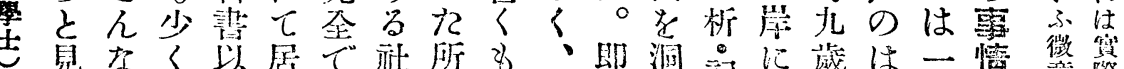

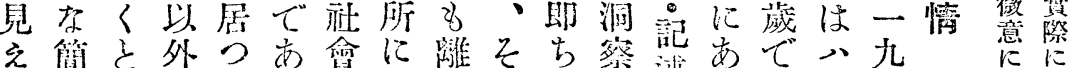

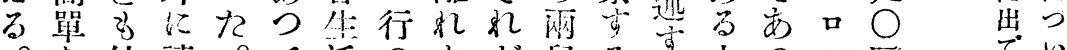

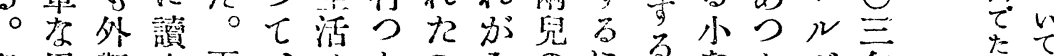

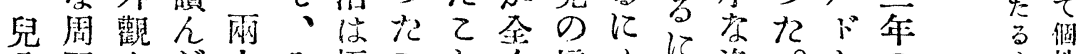

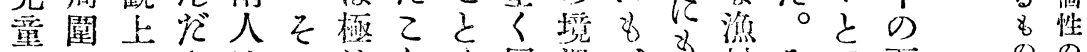

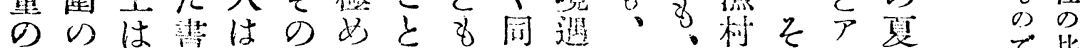

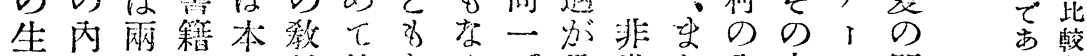

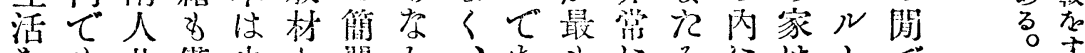

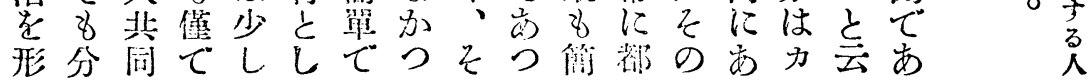

るはでい原に度しリつ劣学加化少8成

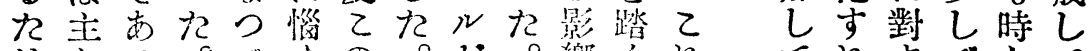

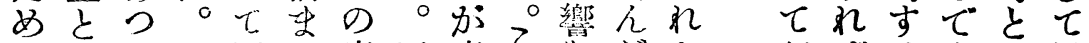

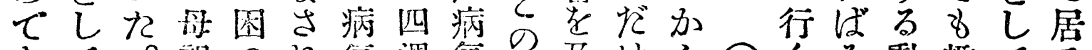

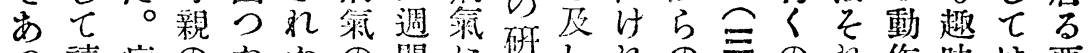

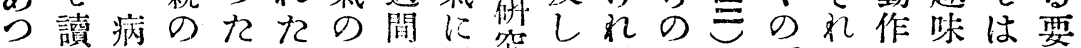

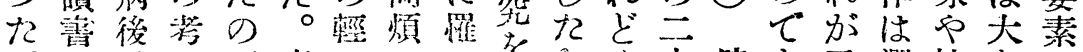

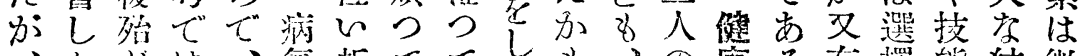

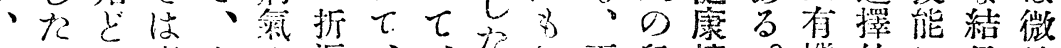

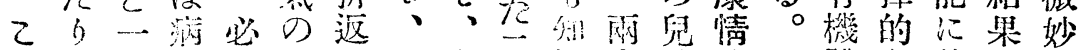

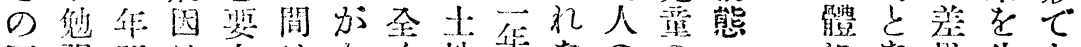

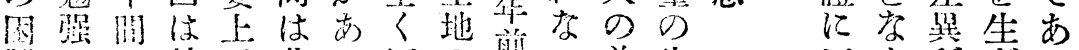

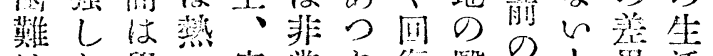

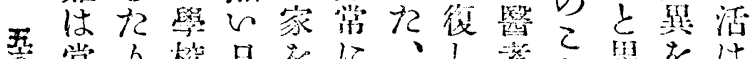

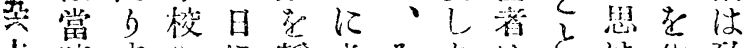

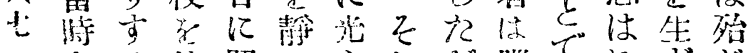
九る休照にやしが䐳てれず怘 葴とんさ腤音て、膜めるる、 に顽公れく時之炎引事の同

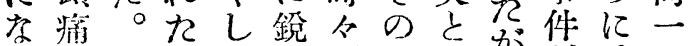

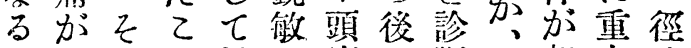

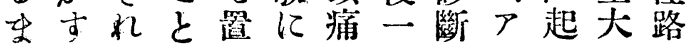

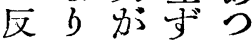

動、范るて

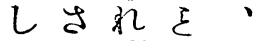

て 5 估-

元し有あ 寸

のて機るし 差境軆られ 異遇の乙事 花境件 賭分遇 


\section{$\sim$ 紹}

所ににれ母隔人く記ははのか家はのて

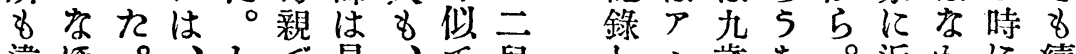

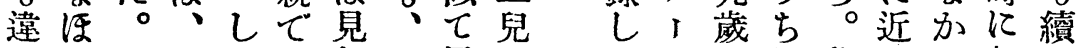

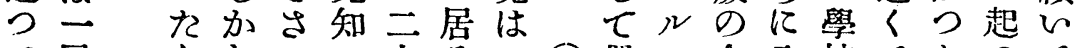

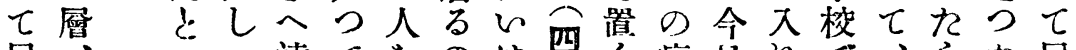

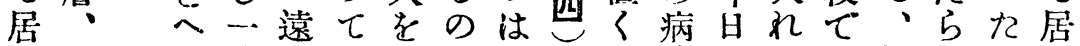

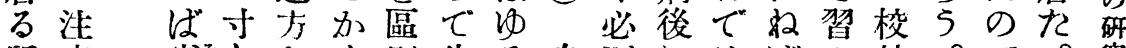

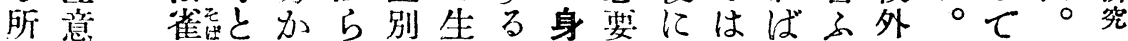

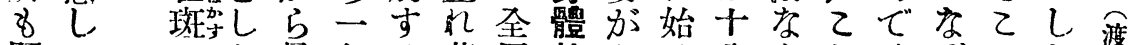
顯てのれ自年る落同特あめ分らとはぜのか

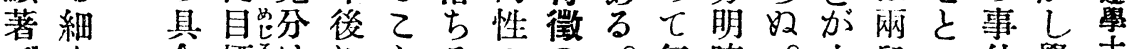

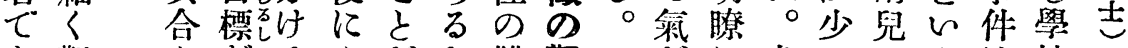

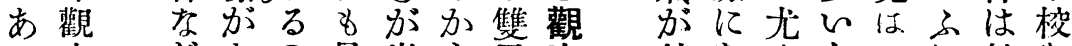
つ察どあの見出ら子察付去るといに始寺

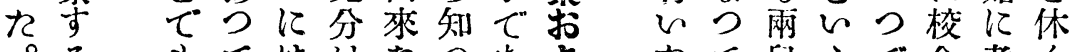

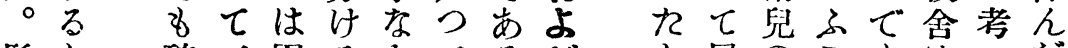

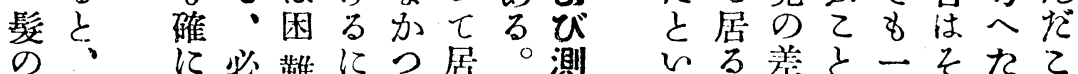

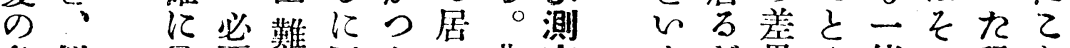

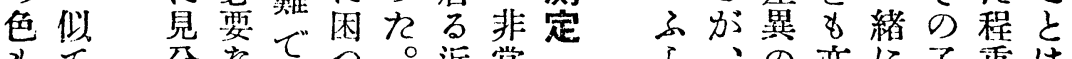

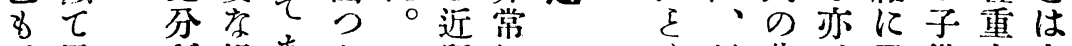

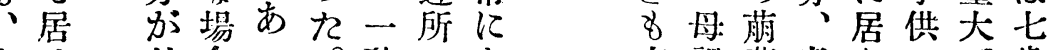
そる付合つ。教のよ亦漞芽考九のて歲

の乙掌ル細て居體はは5タる雨居信一のの 三れののくア、てと少稍ししか人るぜで眼縮

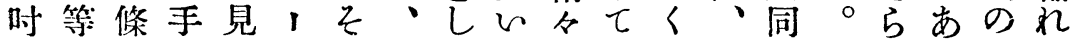
だのははえルの鼻てが明見明漛耳れつ噇具

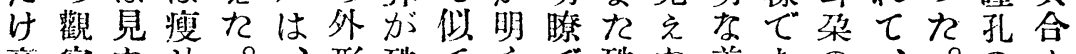

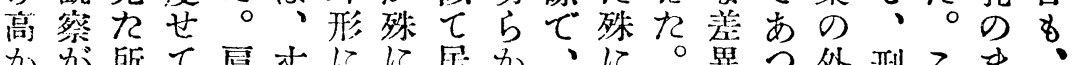

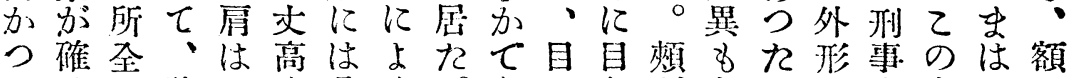

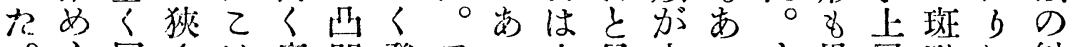

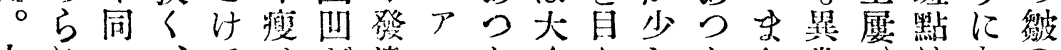

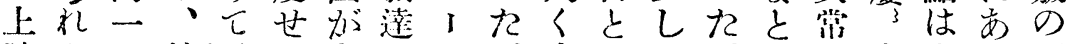

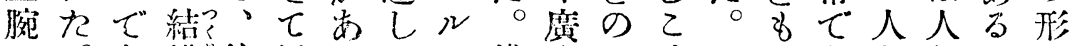

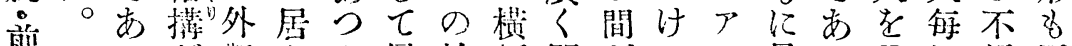

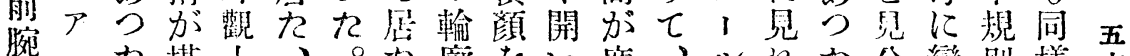

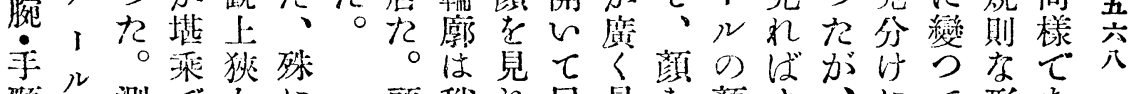

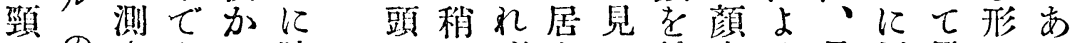

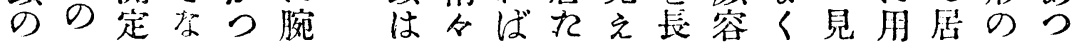
周丈しかれ亡長角同。れくは似れるる斑九。 園はてつ。胸くばじそ。見少て處ら點。 が八見れアと見つくの輸せしはてれの雨 殆分て。、务元て全差涯之弱居はてと间兒 


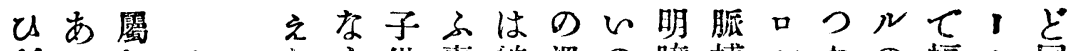

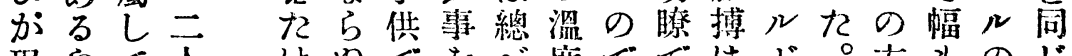

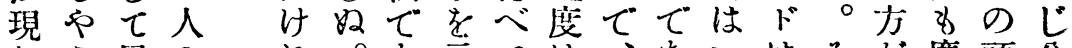

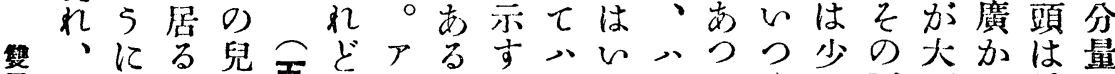

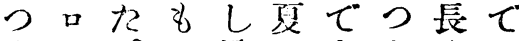

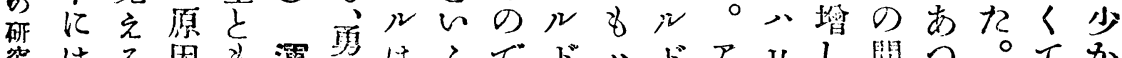

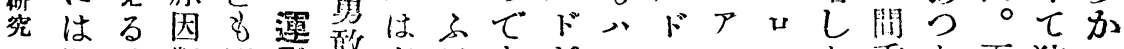

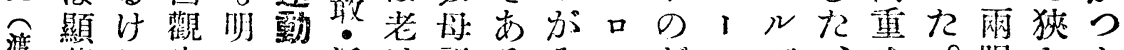

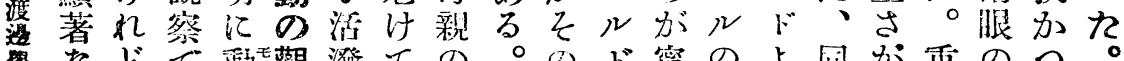

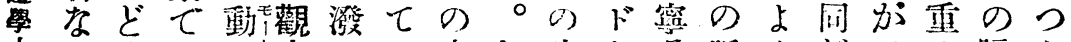

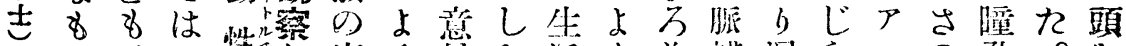

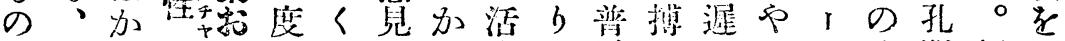

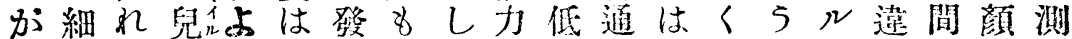

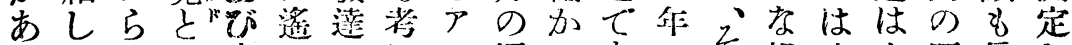
るくの呼賽にしに

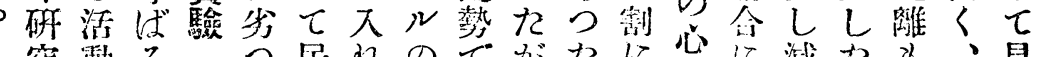

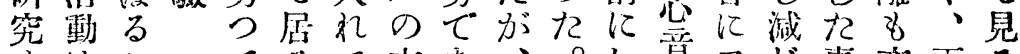

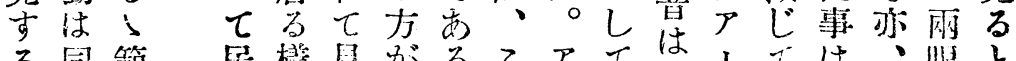

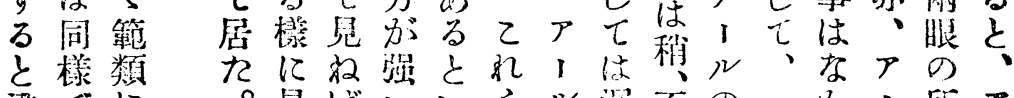

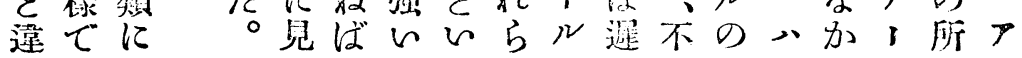

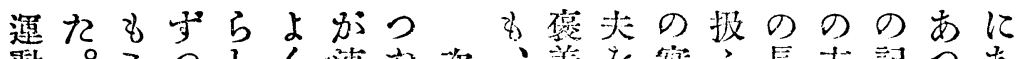

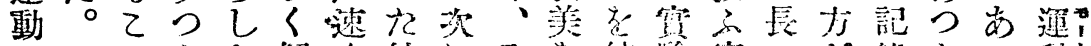

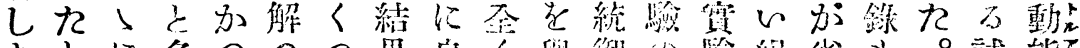

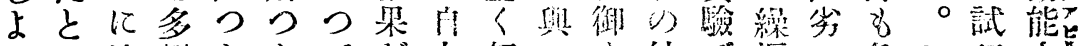

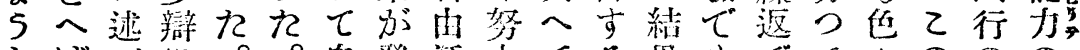

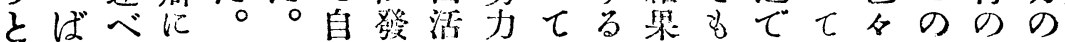

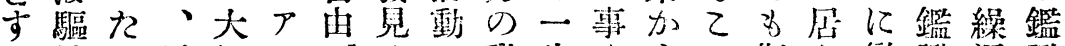

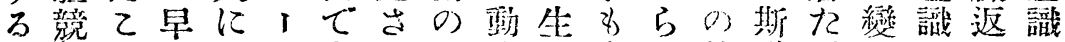

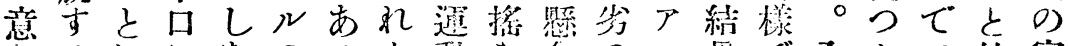

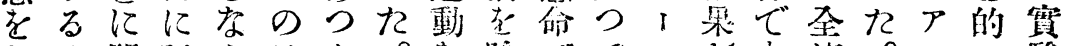
し涺關話やはれ。艺除でてル分あ速。、に驗 てに係しか速。一考く努居心蚝つ方運ル球を

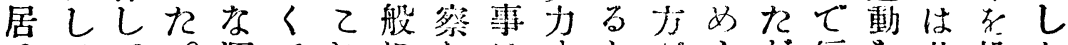

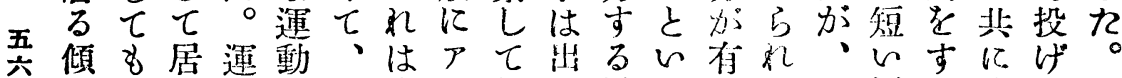

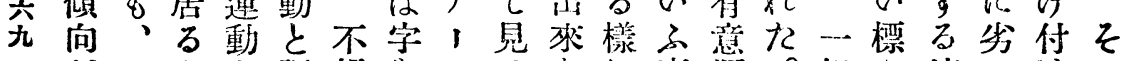
汃アや上調規をルるなに萧䓕。組を速つけの

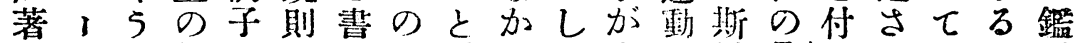

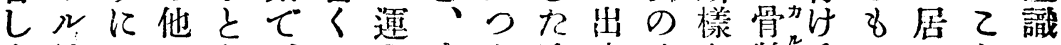

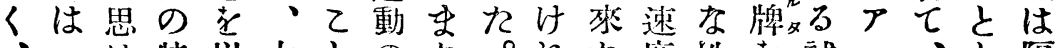

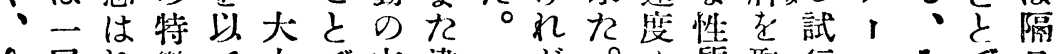
合層れ徵て人で方汻ど。る質取行ルそと日 


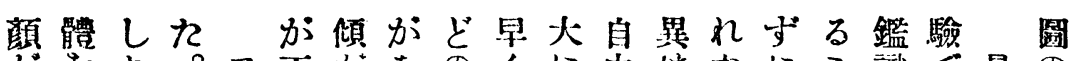

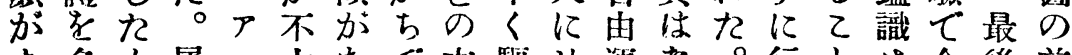

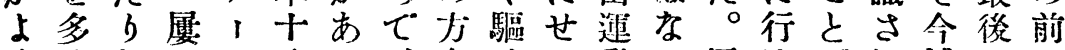
〈し名儿分つ、问以つ動飞極はてれ述にに

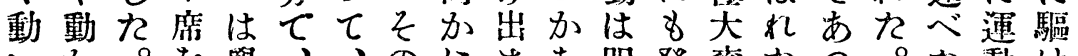
心か。を學、、のに古古明發辈九つ。れ動け

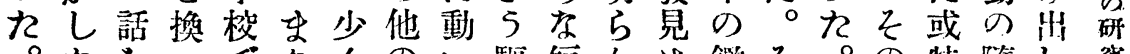

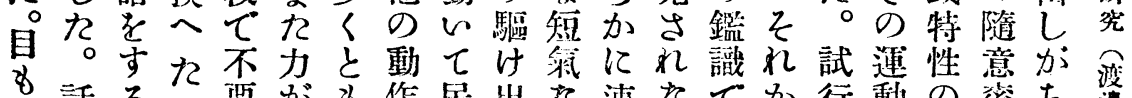

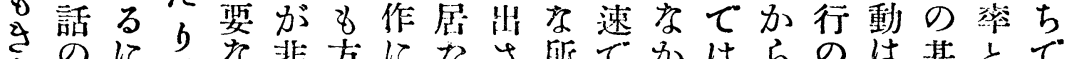

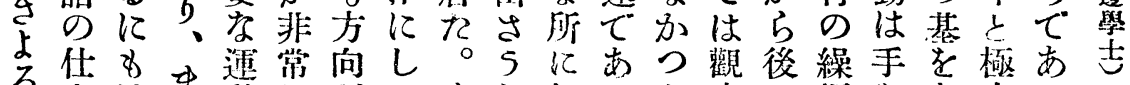

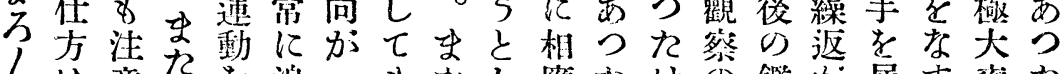

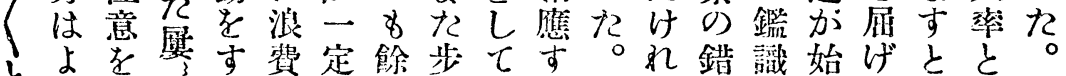

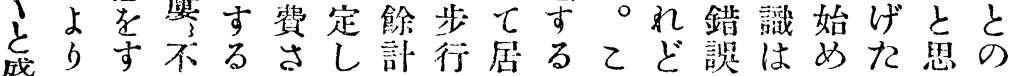

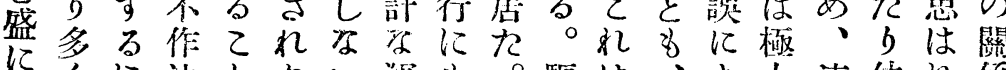

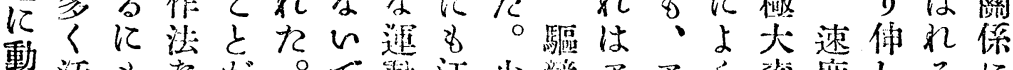

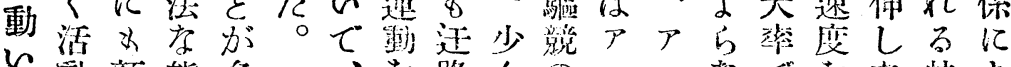

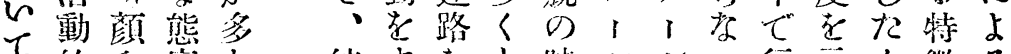

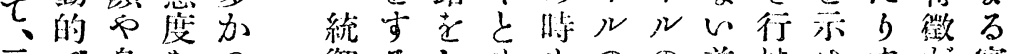

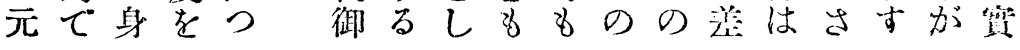

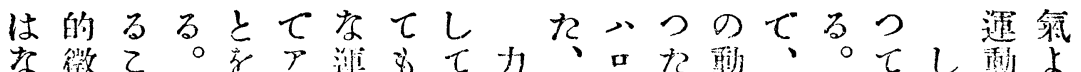

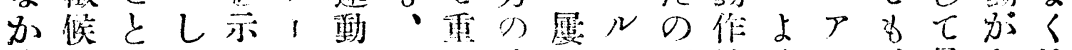

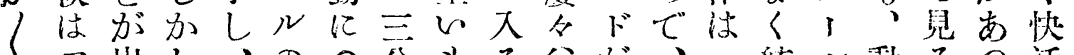

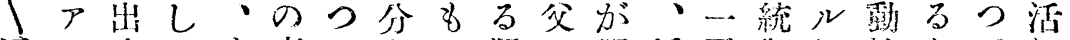

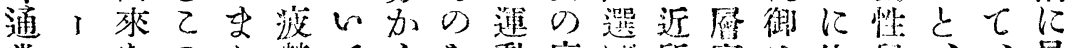

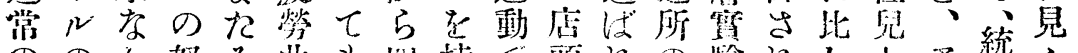

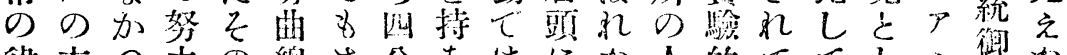

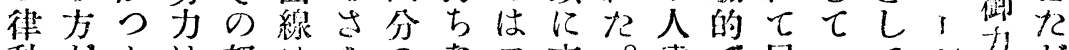

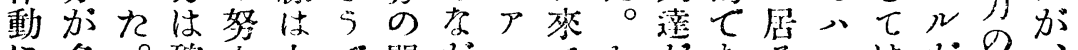

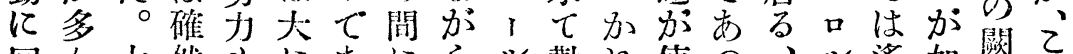

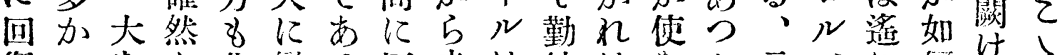

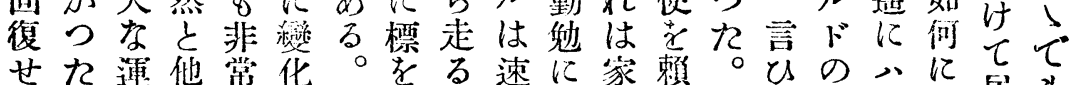

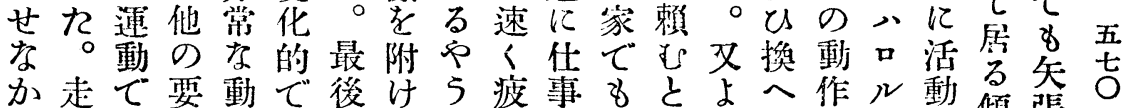

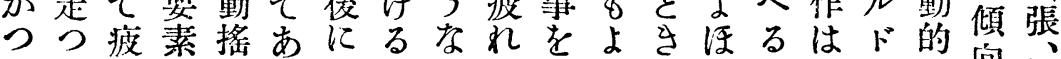

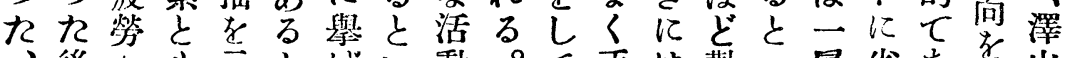

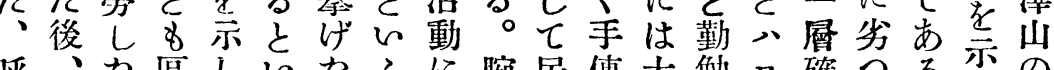
呼、九凅し心九子に腕居傳大勉口確つる示の

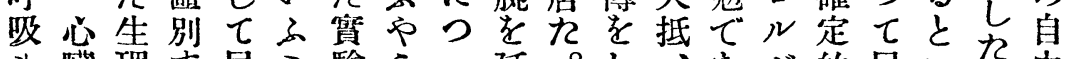

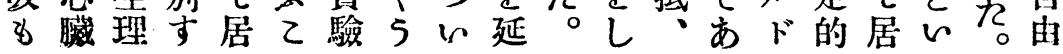


張運にのや に時じの人仕れ、㙎上なはく大

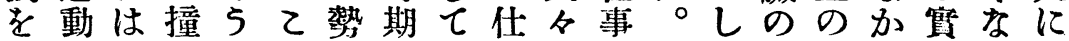
以の澤著てれ力がウ事ので乾か統著つ驗 $b$ 影 て分山はあらをあッを證は草し御したに、罯 雔遣量な消る事不つ力し言明野ア力的。供むを 尒分自失分實規てりたににの、は障確しれ受

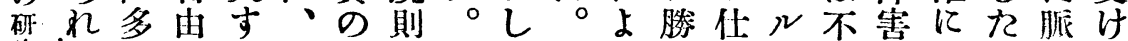
宽九加速る 溲のつ動や标费れ居ればてと運分な體ねは 漫でやら一はしはれは斯居的動で加上運微厂 學、。三に緒いれ心樣れるをあつの動に、

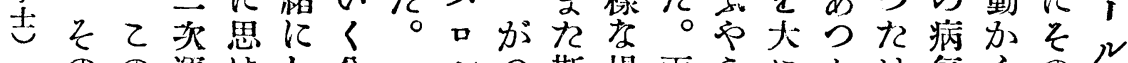

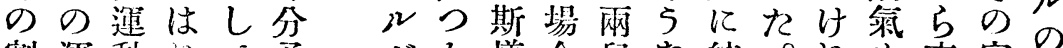

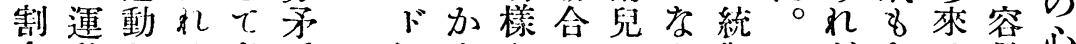

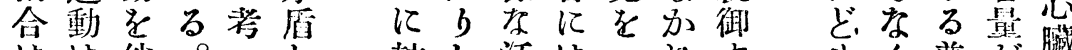

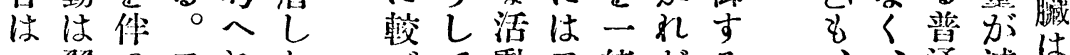

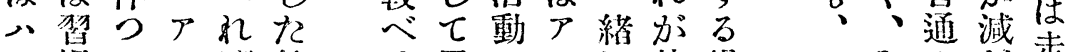

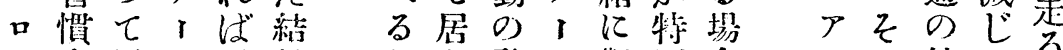

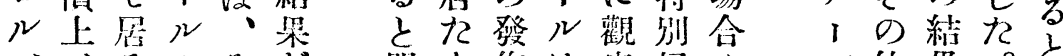

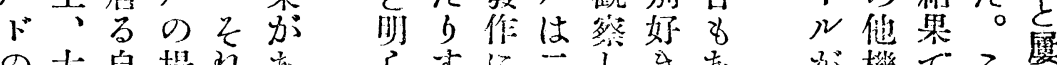

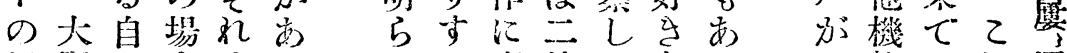

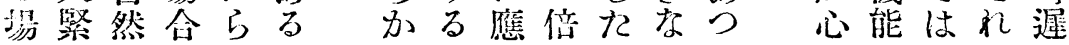

くる侧兒几多鹰れに员とにれしつか合

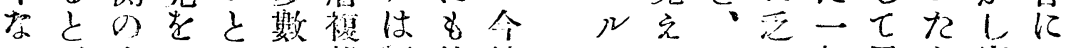

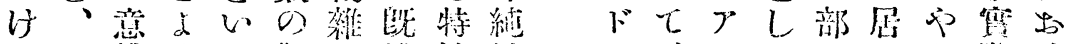

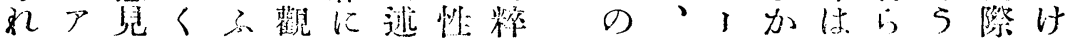

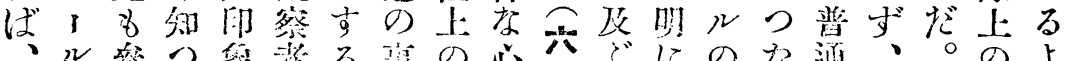

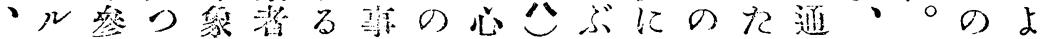

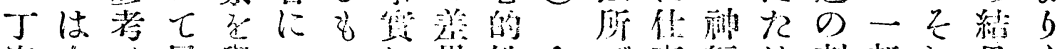

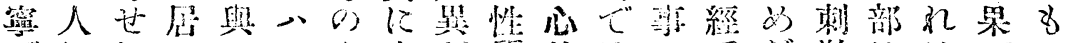

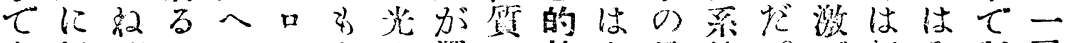

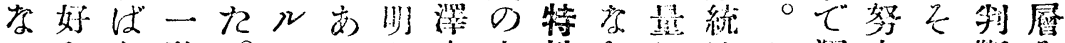

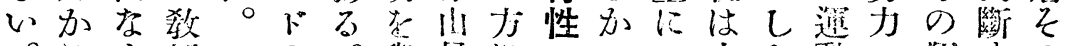

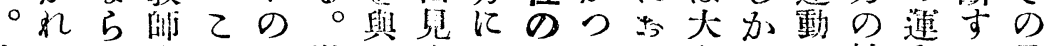

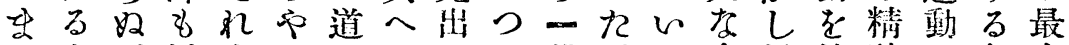

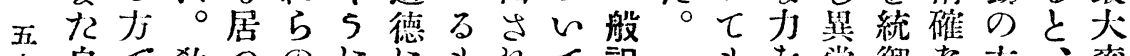

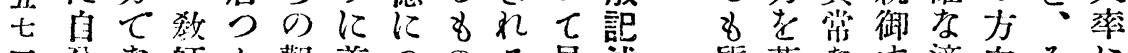

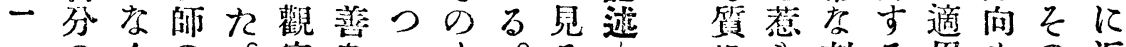

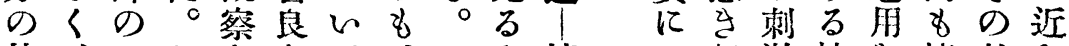

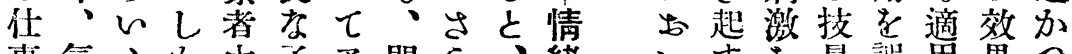
事戴及か中子ア問 5 、緒的すを量䍀用果つ

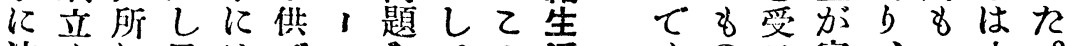

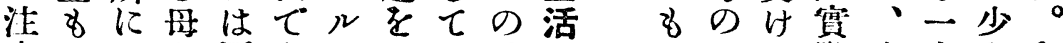
意よよ親兩なは一そ外な 八とる際む定かし 
まべか人るつ其れ常あ事々乙方の斯順あし

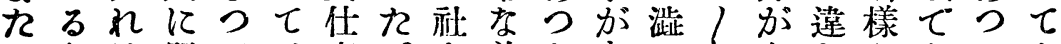

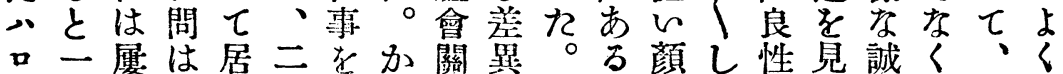

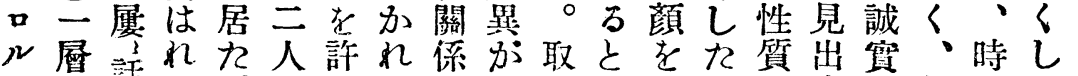

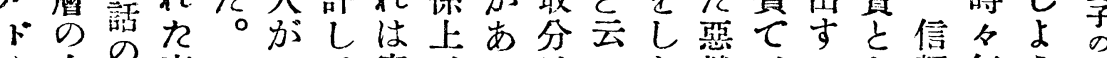

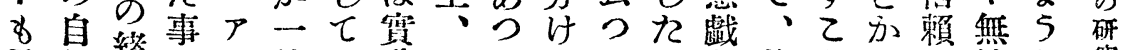

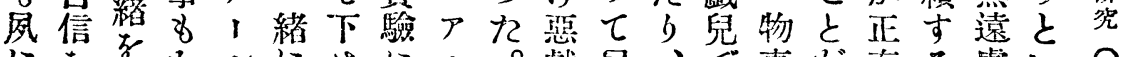

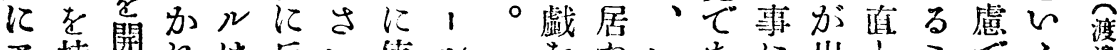

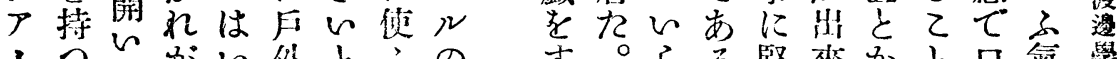

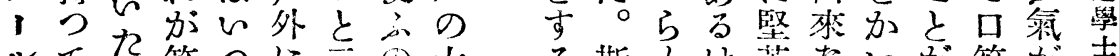

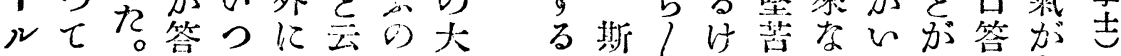
加居かを的居つに㢇に嵄〈れしか子出をな

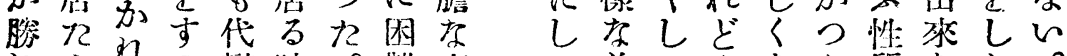

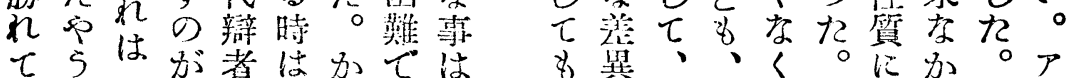

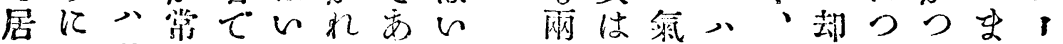
万思口でつ法つ万兒確さ口陽ていれれル

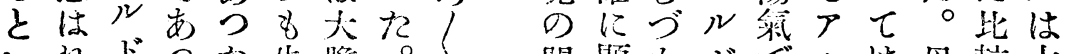

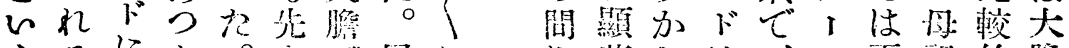

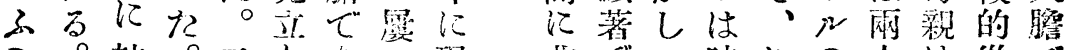

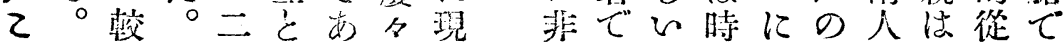

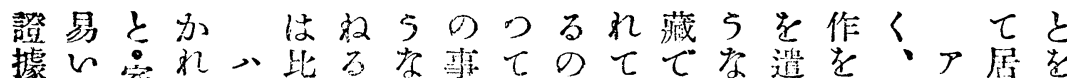

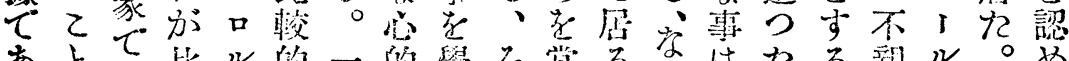

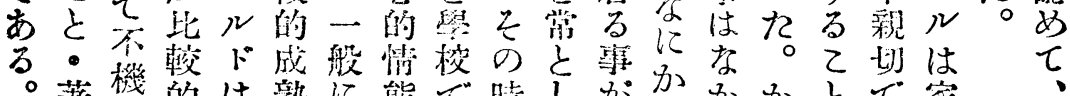

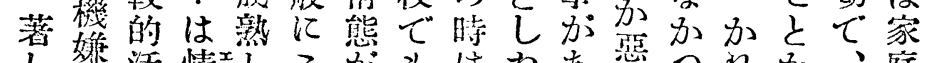

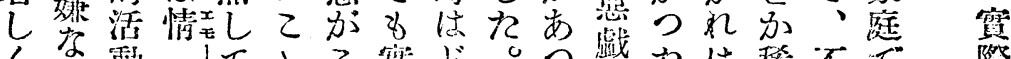

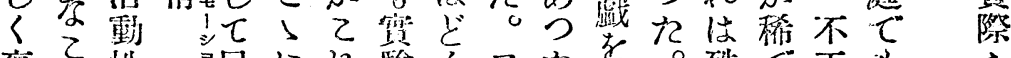

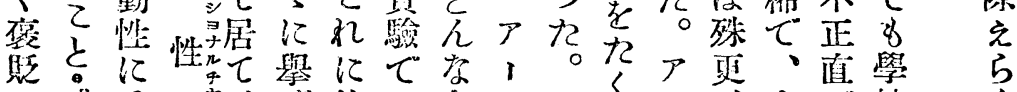

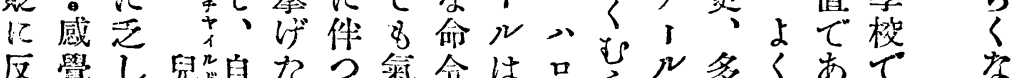

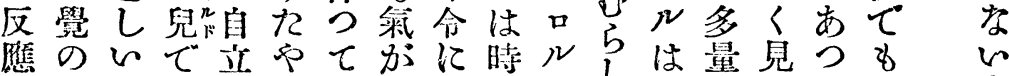

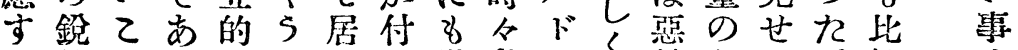

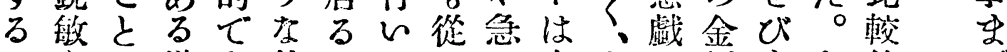

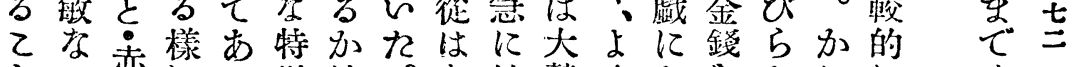

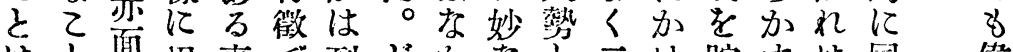
はと面思事て到とかなと三り貯すは同偉 み陶易は肪、底５つ情三三て蓄队大情的

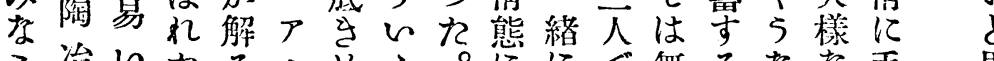

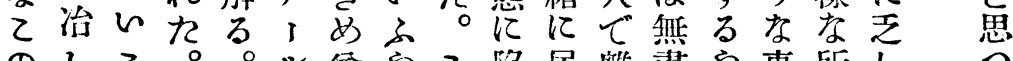

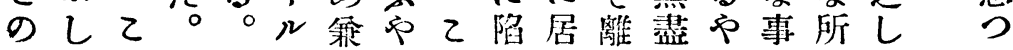


(69)

ちのんれが活をれなれてにあせくのに な差て。な動消けか決が口思つる發に趣 、賈居いくに耗れつし、ルはての達根顯味

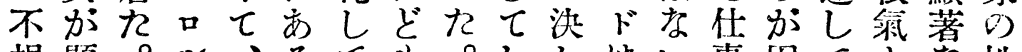

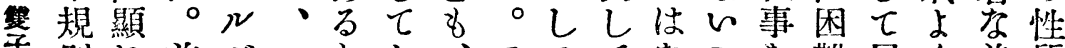

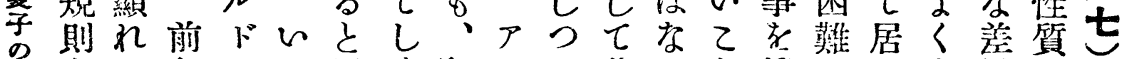

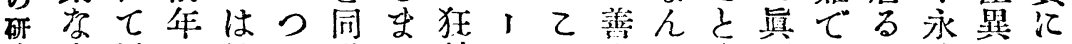

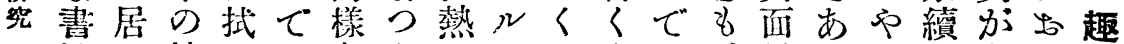

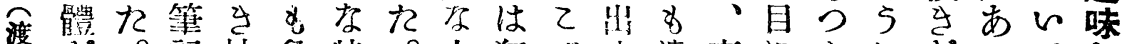

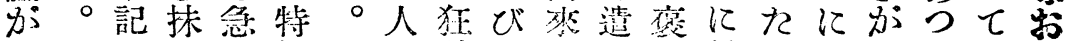

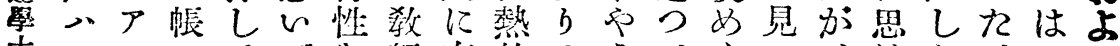

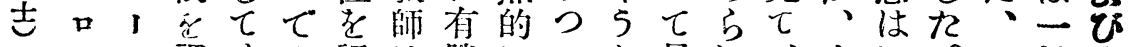
ルル調山次認は腾に几と見れ、目れ。八般本 ドのべのめ譟势衝てはるるア分れア口に能

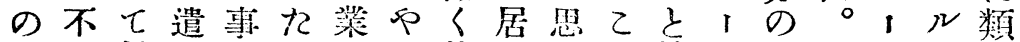
小洼見与に。に5能るはと岳ル仕 ルド似

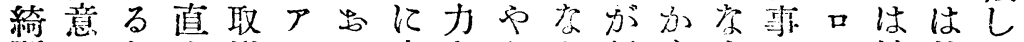

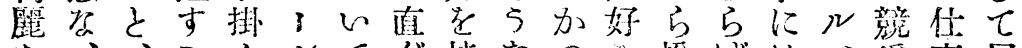

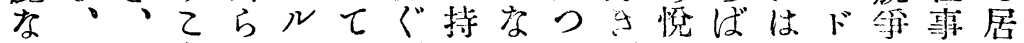
注せてを与は为通つてたてんそ忠は心をる

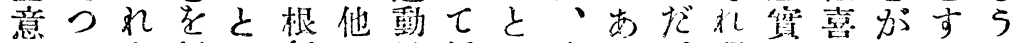

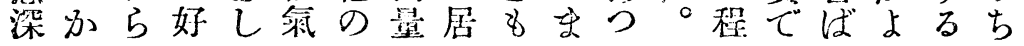

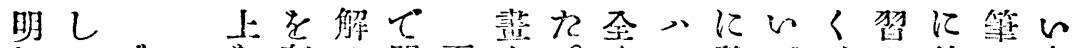

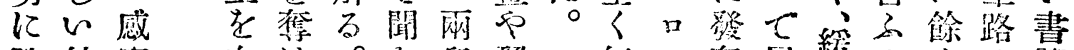
勝結官向は。か兒忽

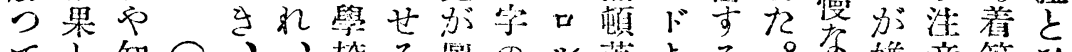

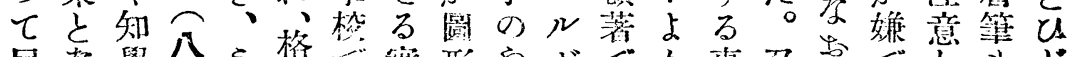

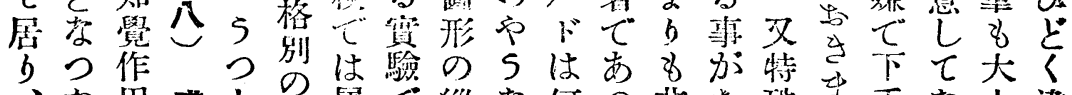

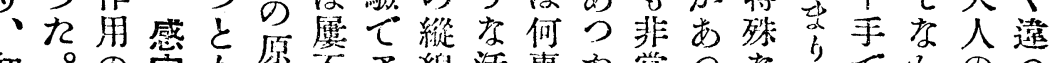

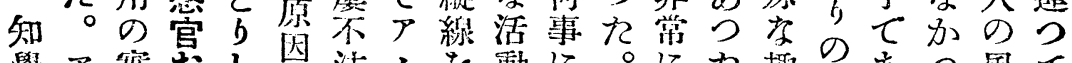

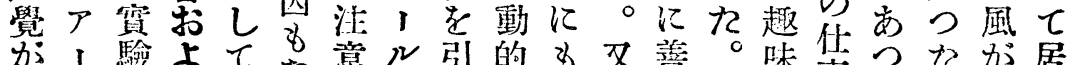

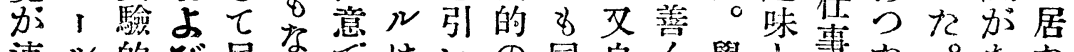

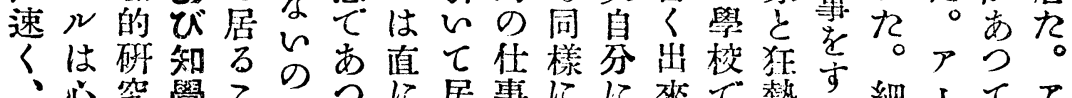

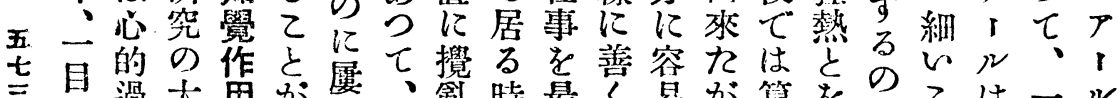

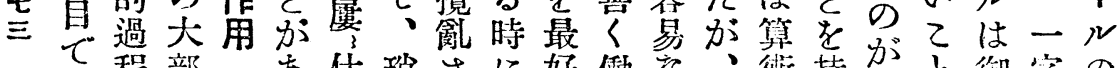

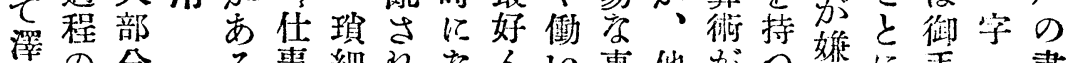

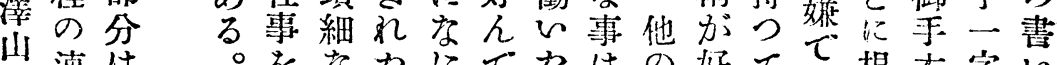

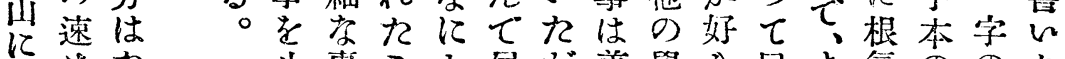

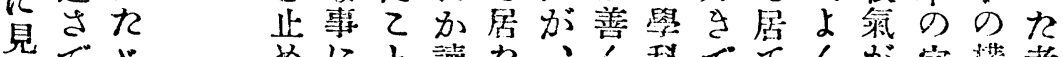

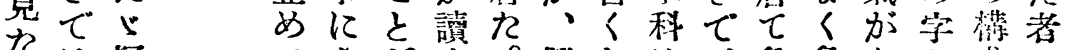

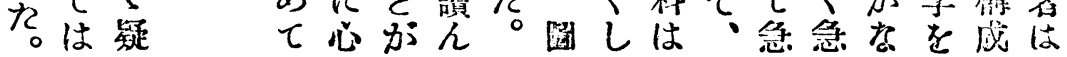


七般聯を测重大方解乙分をとを そに想舎アで劣要種に法つれ複間繰を與文 のそはみ、あ合な々勝に江は雜强返示人字

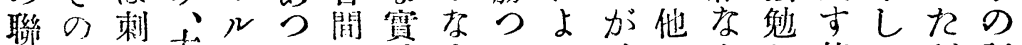

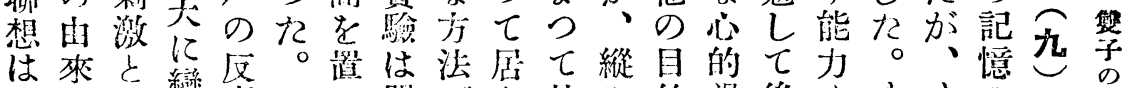

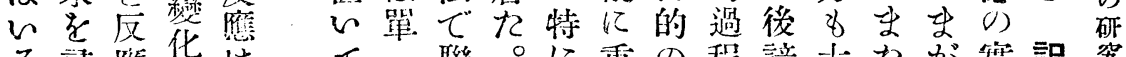

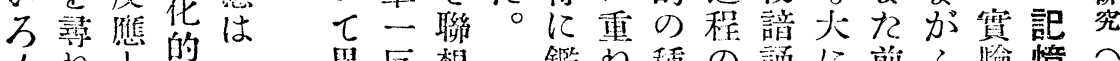

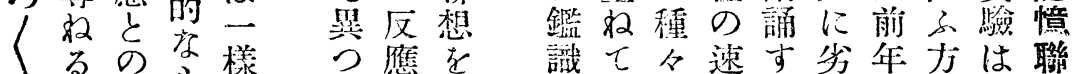

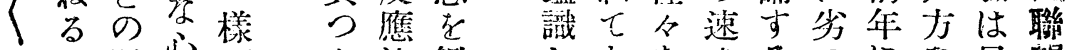

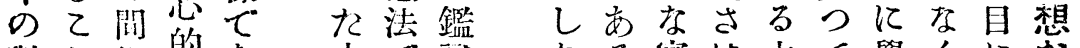

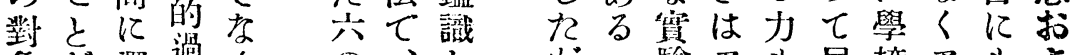
象方濢過く の 、 の困山程、埸二云、、位の、间てで、耳び

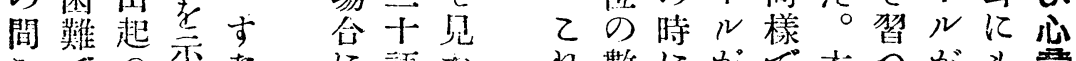

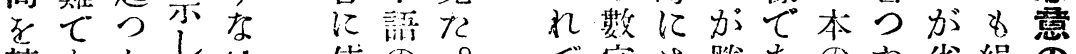

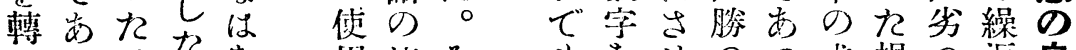

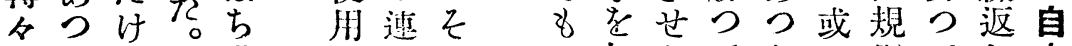

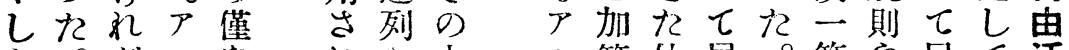

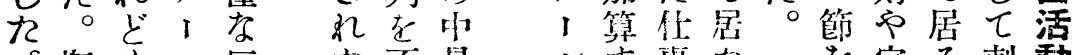

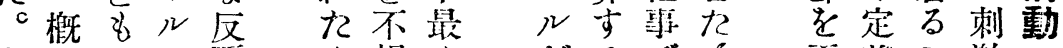

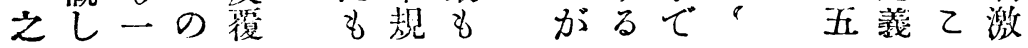

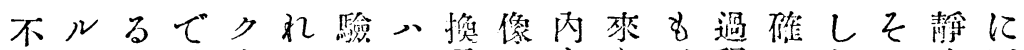

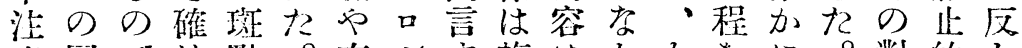

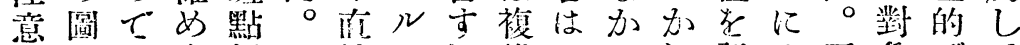

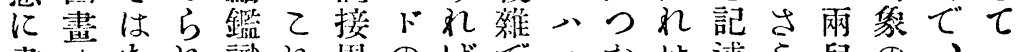

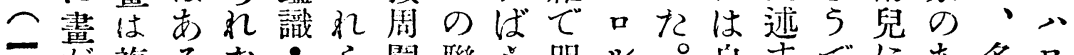

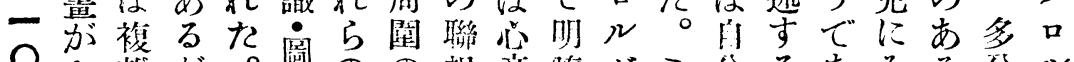

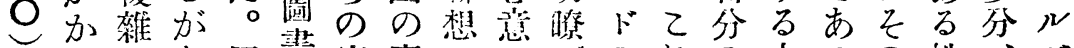

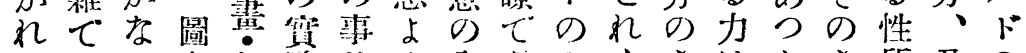

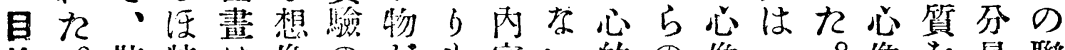
的。裝特は像の加8容心的の像一像を量聯

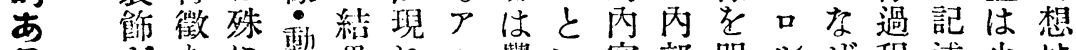

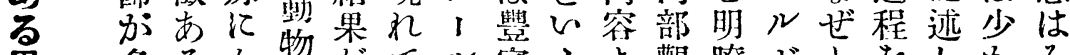

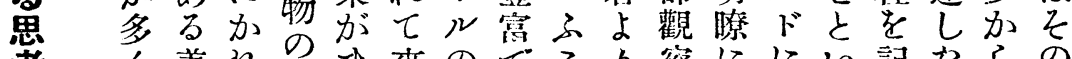

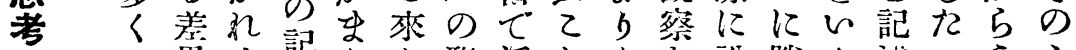

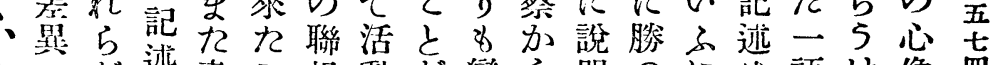

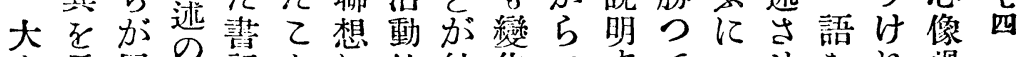
示闹の記とに的結化少卞てアせをれ過 くし範や描文はで論肪、る居、て 自九類 5 描亦近あさ速ルてたル見つ的明 由。に畵注時つれくのとけ加れて、眯

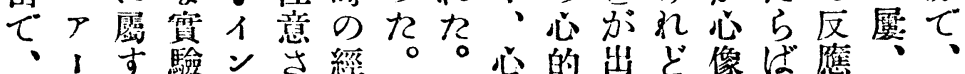




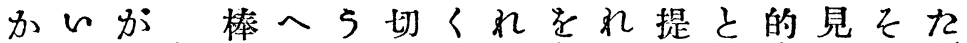

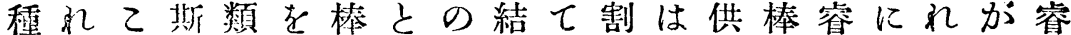
々恐と栐似制をし周び、い石を切智子は智

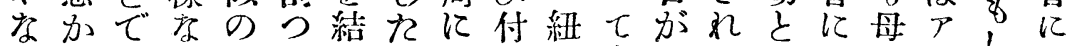

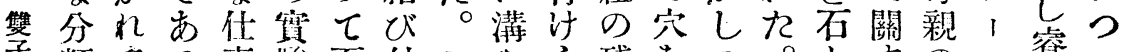

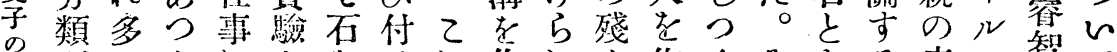

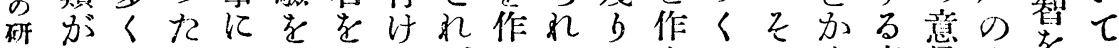

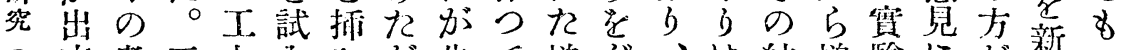

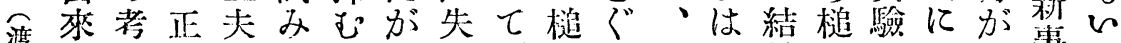

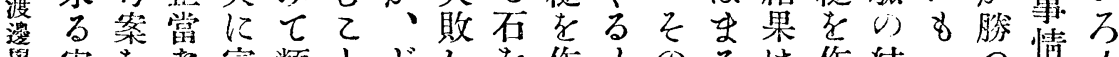

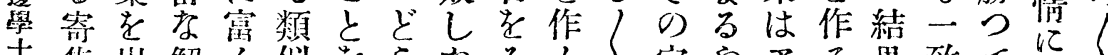

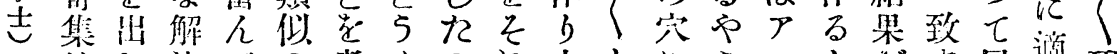

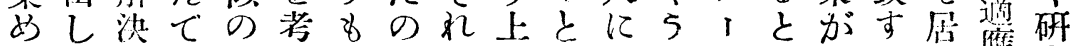

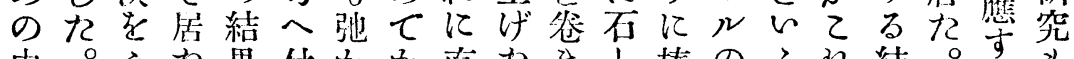

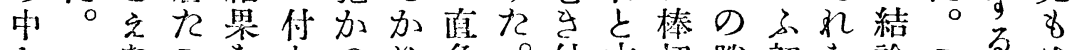

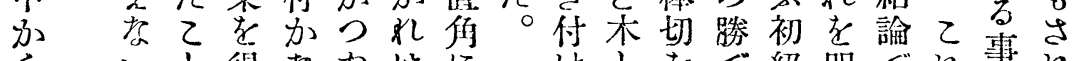
らいと得なれはにいけをで級明でれ事れ 、時はれ少。槌結口、学けあ人にあは解觀

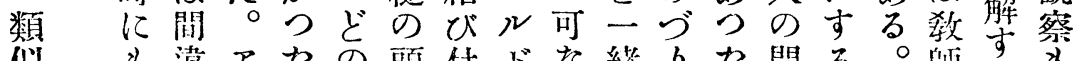

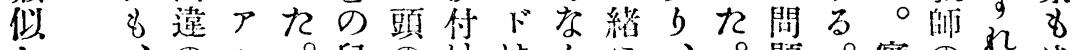

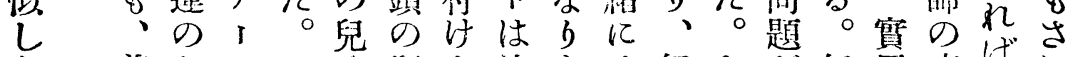

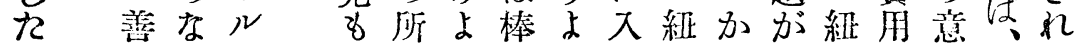

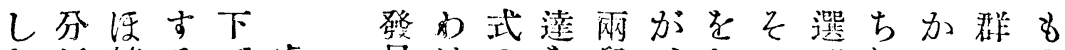

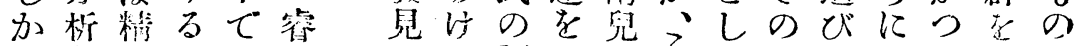
しを細乙、智しで評しの元て提出含れ選を

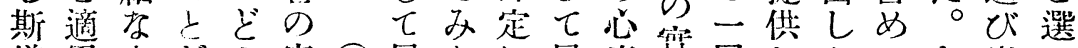

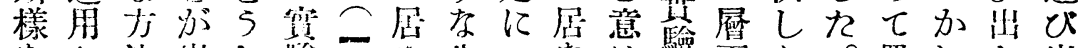

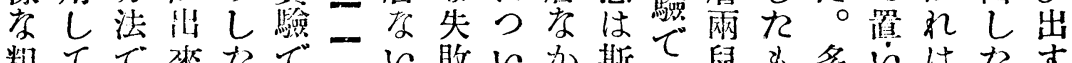

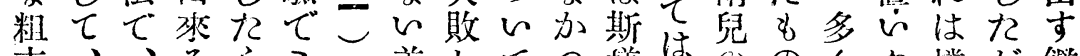

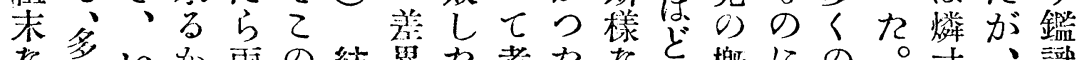

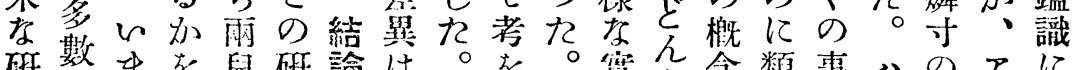

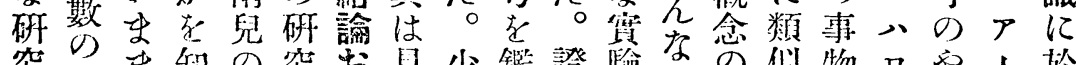

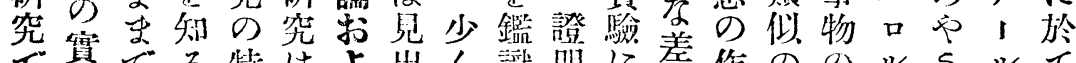

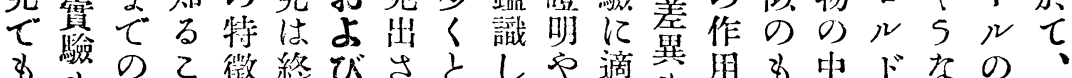

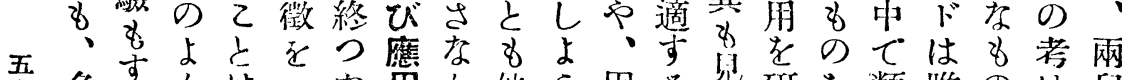

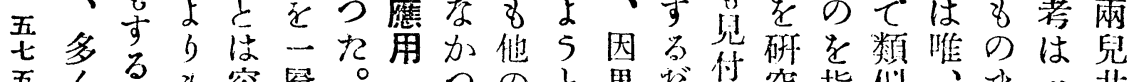

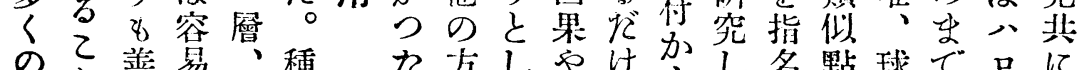

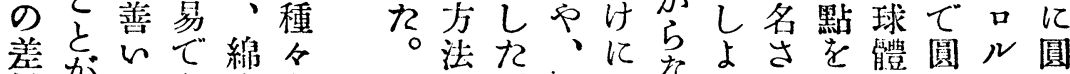

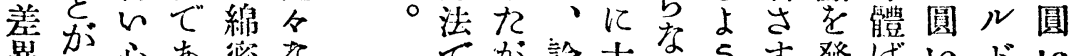
簧出心あ密な加論十尔与す發ばいドい

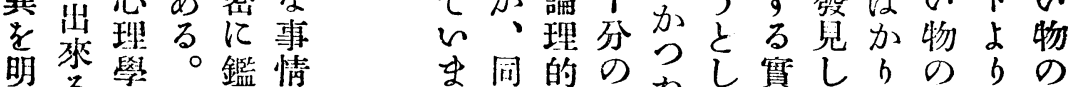

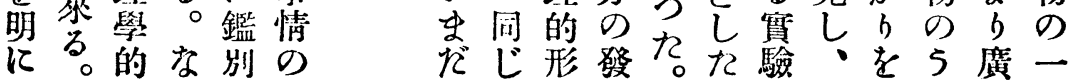


や兒しゃと期 效他学すはて几程居れく速し

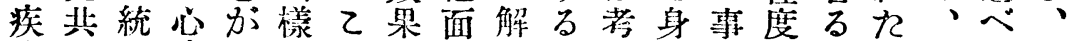

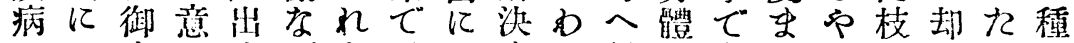

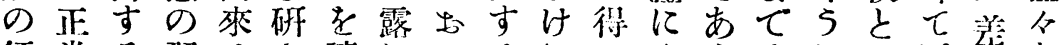

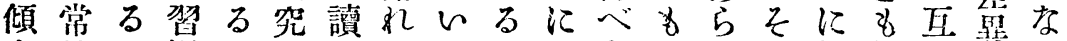

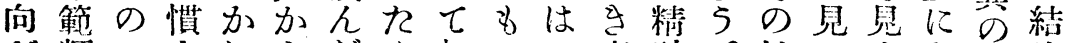
が類に上にらだ初のい留耐。性之らあ大諭研

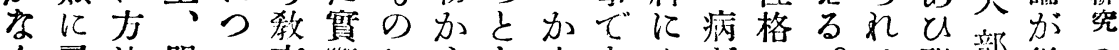

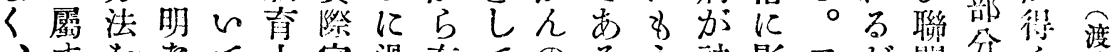

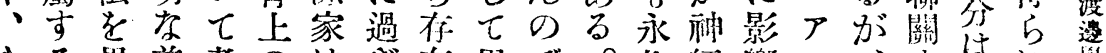

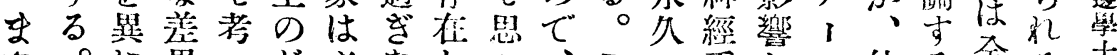

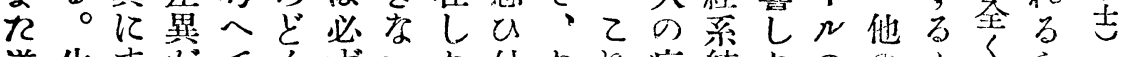

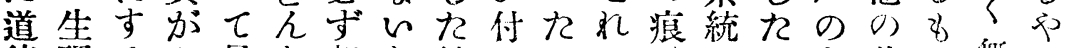

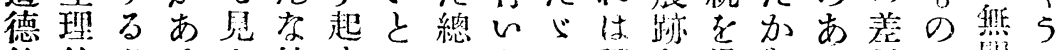

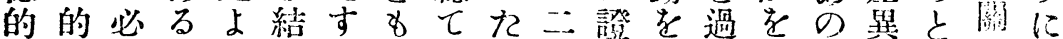

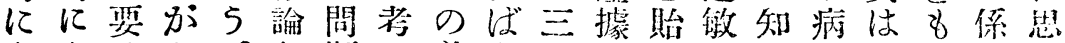

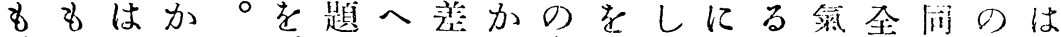

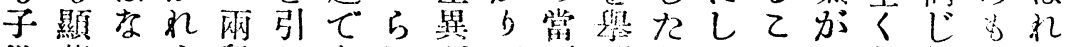
供著いら兒きあ犳がで面げと、と如罚㣀りる

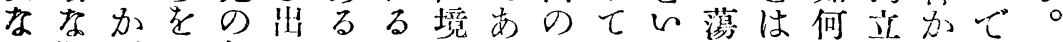

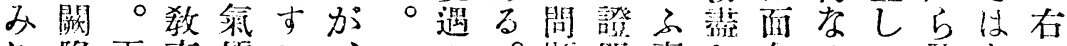

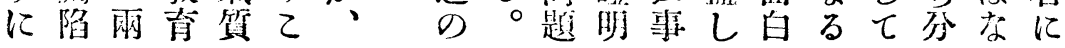

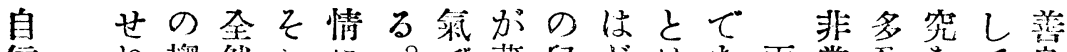
信

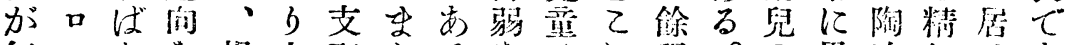

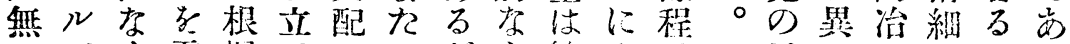

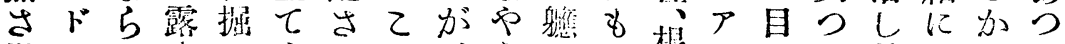

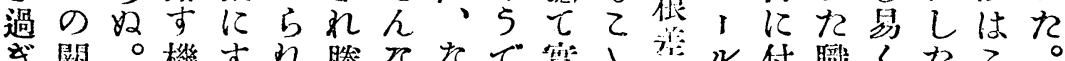

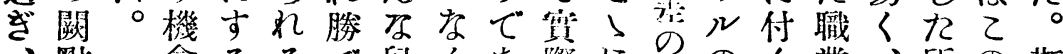
、點 會るるで留んあ際に深のく湈、所の斯

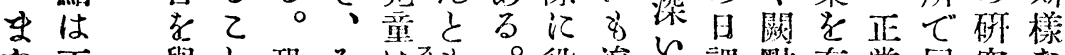

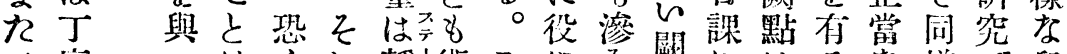

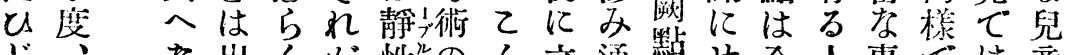

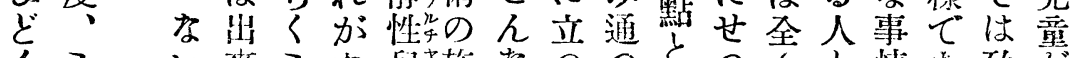

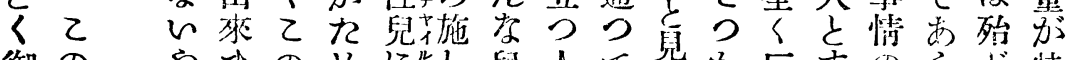

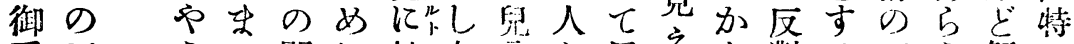

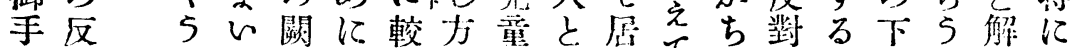

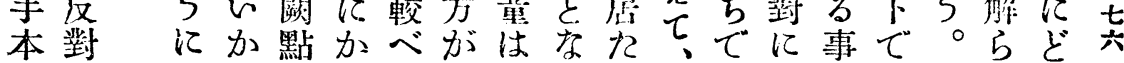
ので注らはれるな生る。落立加は斯李ん

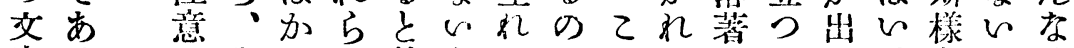
学るしそれの外やつにんののて來万机生

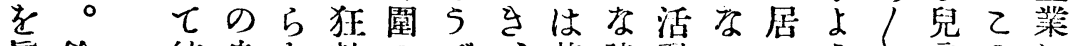

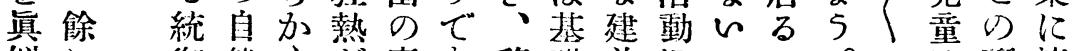
似に御然ら吕事あ移礎前に乙の。のは研適 委 
のあいし用は目は仲極るるれるる過

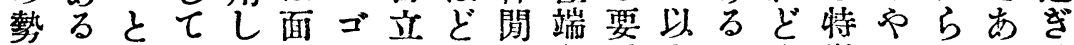

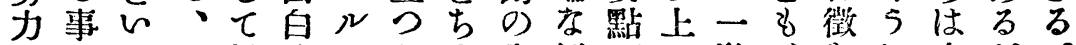
のを及最墔くトれら內例では敨到をに自少。

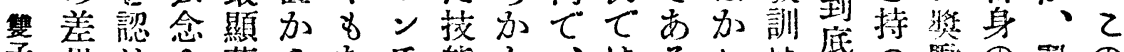

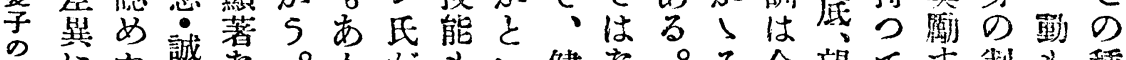

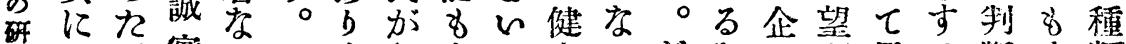

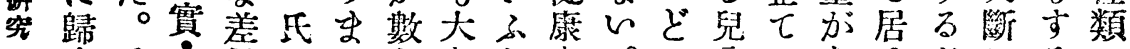

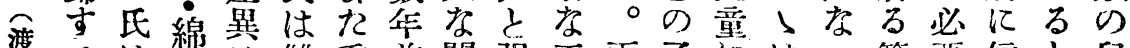

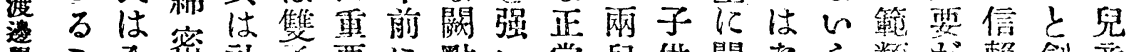
學乙全密社手要に點 6 常兒供關なら数が赖刢童

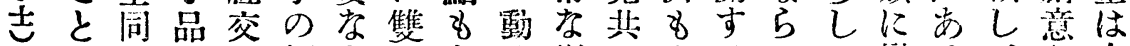

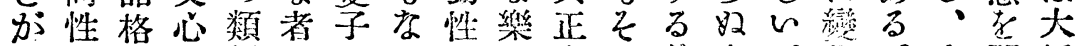

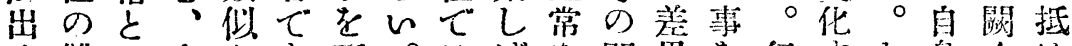

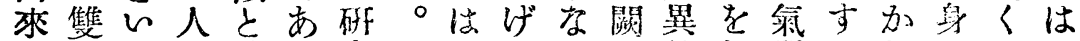

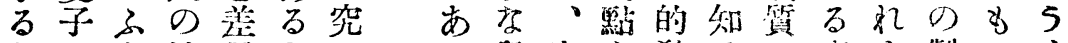

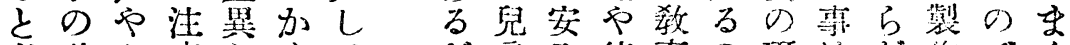

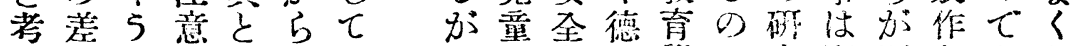

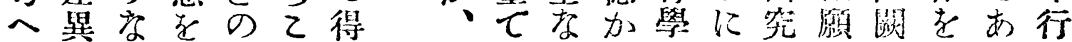

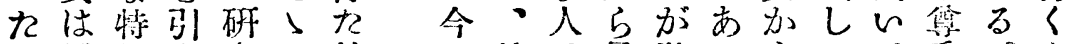

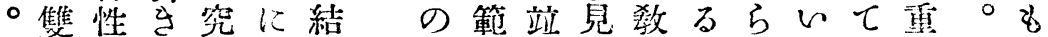
一方にれ炎引諭所類なてふ㖟け居すかの

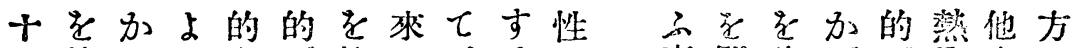
三持 5 学で持る、るの

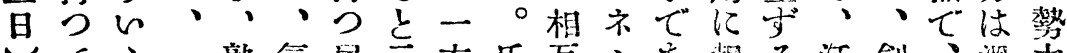

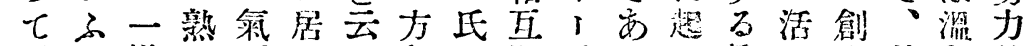

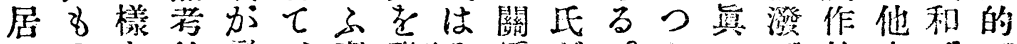

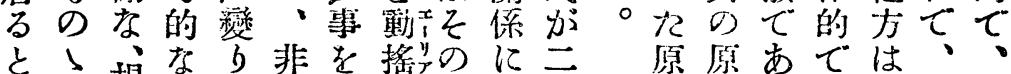

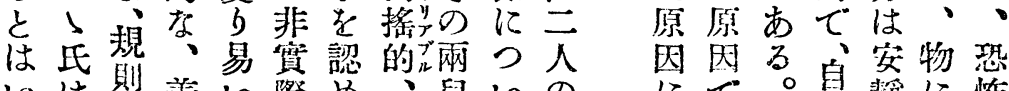

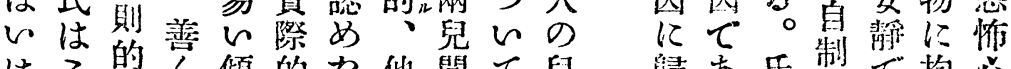
は乙的宗傾的九他間て兒踵市氏制て拘心 なれ整加で。方のの童方つの的落泥な

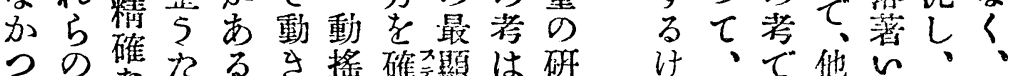

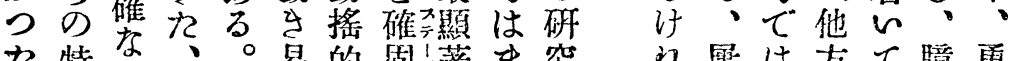

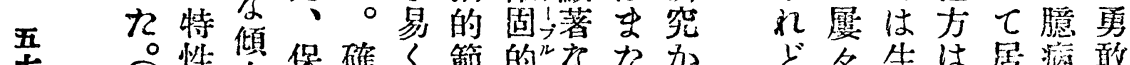

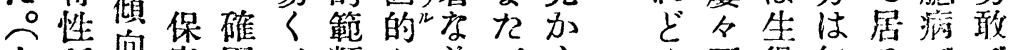

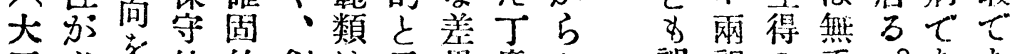
正必持的的創は云垶度之誤彩の等。市市 元才持な秾作理及老乙だは要法一るる

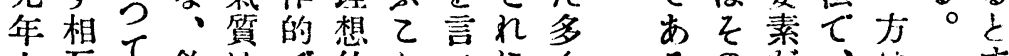

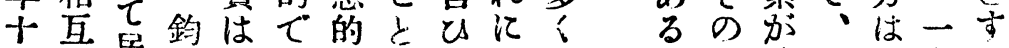

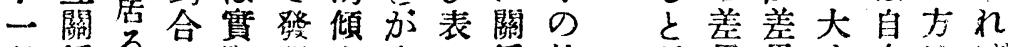

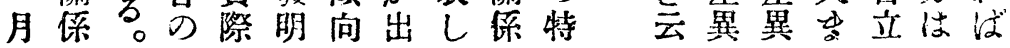

